\title{
Investigating Teacher Candidates' Beliefs about Standardized Testing ${ }^{\mathrm{i}}$
}

\author{
İsmail Kinay*, Tuncay Ardıç \\ Faculty of Education, Dicle University, Turkey
}

Copyright $\bigcirc 2017$ by authors, all rights reserved. Authors agree that this article remains permanently open access under the terms of the Creative Commons Attribution License 4.0 International License

\begin{abstract}
The purpose of this study is to examine the beliefs of prospective teachers' about standardized testing in terms of some variables. This piece of research is in survey model. The study is carried out with 442 randomly selected prospective teachers registered in different departments at Dicle University in Turkey during the 2015-2016 academic year. Selected teacher candidates are grouped under 5 fields according to the branches they have registered (social sciences, language education, mathematics and sciences, fields requiring special ability, basic education). The Beliefs about Standardized Testing Scale (BAST) developed by Magee and Jones (2012) and adapted into Turkish language by İlhan, Çetin and Kinay (2015) is used as data collection tool. As a result of the study teacher candidates are found to have moderate beliefs for standardized tests. There is a significant difference between the candidate teachers' beliefs about standardized tests in terms of their gender and fields. Teacher candidates' beliefs about standardized tests do not differ significantly according to the grade variable.
\end{abstract}

Keywords Standardized Test, Teacher Candidates, Beliefs

\section{Introduction}

There are many factors that direct human behavior. One of these is the beliefs of the individual. While making the meaning of his environment and life, people analyze certain events and phenomena through beliefs and in parallel with this belief system they develop certain forms of behavior. Belief is defined as a representation of one's knowledge about the object or the individual's understanding of himself and his environment [1]. Beliefs and systems of beliefs serve as a guide to help one to know and understand the world [2].

Considering the determinative role of beliefs on human behavior, understanding the educational beliefs of teachers and teacher candidates is important for the development of teaching practices and for the potential success of educational reforms [3]. Because the primary factor that directs teachers' in-class practices is their beliefs. Educational beliefs that teachers have, provides a window on their decision-making, practice and the effectiveness of teaching practices [4], [2]. In this context, one of the beliefs that teachers and teacher candidates possess and needs special attention during the teaching and learning process is the beliefs about standardized testing [5].

According to [6], the origins of standard tests are based on ancient China, where government tasks were mainly given according to the test results of questions about Confucius philosophy and poetry. The use of standard tests for children is seen in IQ tests of French psychologist Alfred Binet. With the development of Cliff Stone's first standard success test in 1908, standard evaluation has started to focus on success rather than intelligence. Tests were also used to assess the capabilities of potential officers by the US Army at the end of World War I. In 1958, American President Eisenhower to compete with the Soviet technological developments, and in particular the launching of the Sputnik; implemented the National Defense Education Act which has allowed state funds to be used to raise student test scores, educational performances, and test success [7]. According to the A Nation at Risk report published in 1983, in the period from 1963 to 1980 , math and verbal tests mean scores of the students in the United States dropped about 40-50 points [8]. After George W. Bush's No Child Left Behind Act of 2001, the Obama administration with the Race to the Top Initiative 2009 initiative has set performance standards for teachers and administrators, linking provincial funds to standardized test results [7]. The No Child Left Behind Act requires students to achieve sufficient success in reading, mathematics and science. Student achievement is measured by standardized tests that are applied to all schools in the same way. The main reason for this is to establish uniform success standards to measure student achievement [9].

Standard tests are assessment instruments that are administered and scored according to predetermined 
standards [10] with a test manual that explains in detail the methods to be followed in the interpretation of the application conditions, scoring principles and scores obtained [11]. Standardized tests are developed according to accredited test development standards. Anyone who takes the test is asked the same questions, and all participants take the test under the same conditions. The same instructions are given to the students about the test and they are given the same duration for the test. The test scoring method is the same [8]. Those who are in charge of applying the standard test must follow the same directives, materials and processes, and make assessment and evaluation according to the criteria specified in the test manual [12]. The purpose of standard tests that differ in aim and design from other tests is to evaluate and compare the skills and competencies of individuals in a diverse community (e.g. having different educational backgrounds and learning in different institutions) [13].

Today, the most commonly used standard test type is multiple-choice tests that require students to find the correct answers to the questions asked in a particular order within a given time period, from the choices given. All variables in standard tests are predetermined and same for all students. Its high reliability and effectiveness in terms of practicality are among the advantages of standard tests [14] Other advantages of standard tests include:

- Standardized tests can lead to positive changes in the classroom or school setting by making the objectives clearer for teachers concerning curriculum that they need to focus on [15].

- They are more objective and reliable than other assessment tools in measuring student access in a given area or areas. They also help teachers and administrators monitor the effectiveness of teaching methods, instructional materials and the new program [16].

- As they are developed by experts, the qualifications of test and test items are high [11].

- Standardized tests allow making international comparisons between students who are at the same level of knowledge and skill [17].

- Standardized tests allow monitoring the student progress objectively and effectively at the end of the specified period [18].

Apart from these positive aspects of the standard tests, there are also some negative aspects. According to [16], preparing for standard tests and the impact on being successful in those tests affects negatively the natural learning process and causes students to focus only on the parts of the subject that will be include in the test. The process of preparing students for standardized tests reduces the amount of time required for teaching, and narrows the content of instructional programs and teaching methods [9]. According to [19], focusing on the results of standard tests can only reflect "teaching the test" instead of more important gains in learning, thus reducing the focus of the curriculum on tests only. When the curriculum is further narrowed, content and skills that are not included in the standard tests are removed from the program. Teachers feel pressure to ensure that the classroom activities are in a way that is appropriate for the materials that are included in the standard assessment [20], even if they believe that other materials will better prepare students for success in real life. Moreover, the disadvantages of standard tests include:

- Standard tests require a lot of time and money. Standardized tests that are punishing the variety in teaching environment can cause students and teachers to hate school [21].

- Standard tests provide very limited information about the student's past or future talent and status. They also have negative effects on teachers' use of various and differentiated techniques in teaching and evaluation [7].

- Standard test-based assessments cause inequality by increasing the gap between the rich and poor students in the long run [22].

- Standard tests encourage students to become superficial thinkers unintentionally, by ignoring qualities that they cannot accurately assess such as creativity, motivation, perseverance, curiosity, and by seeking quick, easy, and clear answers [23].

- Standard tests miss out the internal and mental processes that students experience by focusing only on the correct or incorrect answer [24].

Standardized tests continue to be used to assess student in many countries despite their advantages and disadvantages. It is important to examine the beliefs of teacher candidates for standardized tests in order to get better understanding about the reflections of the standardized tests that emerged as a result of the educational policies of the countries in the teaching-learning process. The beliefs about standardized tests can be defined as the beliefs about the objectivity of standardized assessments, beliefs about high-stakes decisions and beliefs about bonus money [25]. The following questions have been investigated for this purpose;

1. What is the teacher candidates' belief levels regarding standardized tests?

2. Is there a meaningful difference between teacher candidates' beliefs about standardized tests in terms of their gender, field and grade levels?

\section{Research Methodology}

\subsection{Research Model}

This piece of study is in general survey model. Survey models are research approaches aiming to depict conditions in the past or present as they exist today [26]. In this study, survey model is used as it's aimed to describe 
teacher candidates' beliefs about standardized tests.

\subsection{Study Group}

This research was carried out with 442 randomly selected teacher candidates registered in different (12) departments at Dicle University in Turkey during 2015-2016 academic year. The selected teacher candidates are grouped under the 5 fields (social sciences, language education, science and mathematics, special abilities and primary education) according to the branch they study. The demographic information regarding the study group is presented in Table 1.

Table 1. Demographic Information of Teacher Candidates Participating in the Research

\begin{tabular}{|c|c|c|c|}
\hline \multirow{4}{*}{ Gender } & Variable & $\mathbf{N}$ & $\mathbf{\%}$ \\
\cline { 2 - 4 } & Female & 292 & 66.1 \\
\hline \multirow{4}{*}{ Field } & Male & 150 & 33.9 \\
\cline { 2 - 4 } & Social Science & 68 & 15.4 \\
\cline { 2 - 4 } & Language Education & 140 & 31.7 \\
\cline { 2 - 4 } & Maths and Science & 123 & 27.8 \\
\cline { 2 - 4 } & Fields Requiring Special Ability & 40 & 9.0 \\
\hline \multirow{4}{*}{ Grade } & Primary Education & 71 & 16.1 \\
\cline { 2 - 4 } & $2^{\text {nd }}$ Grade & 109 & 24.7 \\
\cline { 2 - 4 } & $3^{\text {rd }}$ Grade & 154 & 34.8 \\
\hline \multirow{2}{*}{ Total } & $4^{\text {th }}$ Grade & 179 & 40.5 \\
\hline \multirow{2}{*}{} & & $\mathbf{4 4 2}$ & $\mathbf{1 0 0 . 0}$ \\
\hline
\end{tabular}

\subsection{Data Collection Tool}

Beliefs about Standardized Testing (BAST) developed by Magee and Jones [25] and adapted to Turkish by Illhan, Çetin and Kinay [27] is used as data collection tool. BAST was developed to determine the beliefs of university students about standardized tests. BAST has 5-Likert type rating and contains 9 items. The BAST consists of three dimensions: beliefs about the objectivity of standardized tests, beliefs about high-stakes decisions and beliefs about bonus money. The reliability coefficients for the scale obtained from the data obtained from the teacher candidates in the Turkish adaptation study were found to be .77 [27]. The Cronbach Alpha reliability coefficient is .65 in this study. [28] stated that the reliability coefficient of .50 and above is acceptable. Accordingly, it can be said that the reliability coefficients of the scale are sufficient.

\subsection{Data Analysis}

Data obtained from the study are analyzed using the SPSS 20.0 software program. Percentages and frequencies for the demographic information for the teacher candidates in the study group were calculated. The mean and standard deviation values are calculated to determine the level of beliefs of the teacher candidates about the standard tests.
Mean scores are interpreted by considering the range of points and levels of the data in Table 2.

Table 2. Intervals and Levels Used to Interpret Mean Scores

\begin{tabular}{|c|c|}
\hline Interval & Level \\
\hline $1.00-1.80$ & Very Low (Totally Disagree) \\
\hline $1.81-2.60$ & Low (Disagree) \\
\hline $2.61-3.40$ & Medium (Partially Agree) \\
\hline $3.41-4.20$ & High (Agree) \\
\hline $4.21-5.00$ & Very High (Totally Agree) \\
\hline
\end{tabular}

In this study parametric tests are used because the data have a normal distribution and a homogenous structure for the three variables used in the study. To determine if the beliefs about the standardized tests of teacher candidates differ according to the gender variable unpaired sample t-test was used. And One Way Variance Analysis (ANOVA) was used to see whether it changed according to field and class variables. In the comparison, significance level was set at 0.05 . LSD test was used to determine the source of the difference and the effect value was calculated to determine the effect size of the significance. According to Cohen [1988], the eta squared between .01 and .06 is small, between .06 and .14 is moderate, and .14 and above is interpreted as the greatest effect (cited in [29]; [30]).

\section{Findings}

The research findings are presented in order with the research questions. The mean and standard deviation values of teacher candidates' beliefs regarding standard tests are presented in Table 3.

Table 3. Mean and Standard Deviation Values Related to Teacher Candidates' Beliefs about Standardized Tests

\begin{tabular}{|c|c|c|c|c|}
\hline & N & M & sd & Level \\
\hline Beliefs About Standardized Tests & 442 & 2.63 & 0.61 & Medium \\
\hline
\end{tabular}

When Table 3 is examined, it is seen that of teacher candidates' beliefs about the standardized testing are at moderate $(\bar{X}=2.63)$ level. According to this teacher candidates' beliefs are in the middle of the scale. Thus teacher candidates can be said neither for nor against these tests. Findings regarding whether teacher candidates' beliefs about standard tests differ according to gender are presented in Table 4.

When Table 4 is examined, it is determined that the teacher candidates differed significantly in their beliefs about standardized tests $(\mathrm{p}<.05)$ in favor of male teachers according to gender. Significant difference $(.141>.140)$ was found to be large when the effect value is examined. According to this finding male teacher candidates have more belief in standardized tests when compared to female ones. 
Table 4. Teacher Candidates' Beliefs about Standardized Tests by Gender Variable

\begin{tabular}{|c|c|c|c|c|c|c|c|c|}
\hline & Gender & $\mathrm{N}$ & $\mathrm{M}$ & $\mathrm{sd}$ & $\mathrm{df}$ & $\mathrm{t}$ & $\mathrm{P}$ & Impact Value \\
\hline \multirow{2}{*}{ Beliefs about Standardized Tests } & Female & 292 & 2.57 & 0,56 & \multirow{2}{*}{440} & \multirow{2}{*}{2,818} & \multirow{2}{*}{0,005} & \multirow{2}{*}{.141} \\
\cline { 2 - 6 } & Male & 150 & 2.75 & 0,67 & & \\
\hline
\end{tabular}

Table 5. Teacher Candidates' Beliefs about Standardized Tests According to Fields They Study

\begin{tabular}{|c|c|c|c|c|c|c|c|}
\hline Field & $\mathrm{N}$ & M & sd & $\mathrm{F}$ & $\mathrm{p}$ & Effect Value & $\begin{array}{l}\text { LSD } \\
\text { Test }\end{array}$ \\
\hline 1. Social Sciences & 68 & 2.69 & .68 & \multirow{5}{*}{3.631} & \multirow{5}{*}{$0.006^{*}$} & \multirow{5}{*}{.179} & \multirow{5}{*}{$1-5,2-5,3-5,4-5$} \\
\hline 2. Language Education & 140 & 2.64 & .56 & & & & \\
\hline 3. Math and Science & 123 & 2.73 & .58 & & & & \\
\hline 4. Special Ability & 40 & 2.65 & .68 & & & & \\
\hline 5. Primary Education & 71 & 2.40 & .59 & & & & \\
\hline
\end{tabular}

Findings are presented in Table 5 to show whether the teacher candidates' beliefs about standardized tests differ according to the areas they study.

When Table 5 is examined, it is determined that there is a significant difference between the teacher candidates' beliefs about standardized tests and the areas they study. When mean scores are taken into consideration, it is found that teacher candidates who study in the field of mathematics and science have the highest mean scores and the teacher candidates who study in the primary education field have the lowest means. Furthermore, when the impact value is taken into consideration, it is seen that the meaningful difference is large $(.171>.140)$. Teacher candidates studying in special ability, language education and social sciences have more belief in standardized tests when compared to primary education counterparts.

Findings are presented in Table 6 to show whether the teacher candidates' beliefs regarding standardized tests differ according to their grades.

Table 6. Teacher Candidates' Beliefs about Standardized Tests by Grade Levels

\begin{tabular}{|c|c|c|c|c|c|}
\hline Grades & $\mathrm{N}$ & $\mathrm{M}$ & $\mathrm{sd}$ & $\mathrm{F}$ & $\mathrm{p}$ \\
\hline $2^{\text {nd }}$ Grade & 109 & 2.62 & .59 & & \\
\cline { 1 - 4 } $3^{\text {rd }}$ Grade & 154 & 2.65 & .55 & \multirow{2}{*}{.139} & \multirow{2}{*}{.870} \\
\cline { 1 - 4 } $4^{\text {th }}$ Grade & 179 & 2.63 & .67 & & \\
\hline
\end{tabular}

When Table 6 is examined, it is determined that there is no meaningful difference between teacher candidates' beliefs about standard tests in terms of grade variable. The mean scores according to the grade level are seen to be very close to each other. But as the candidates move from one grade to another their beliefs are increasing as well. However the change in their beliefs is not statistically significant.

\section{Conclusions, Discussion and Recommendations}

When findings related to the first question of the research are examined, it is concluded that teacher candidates' beliefs about the standardized tests are at moderate level. It can be said that the teacher candidates participating in the research are not against these tests however and they do not fully support the use of these tests either. In addition to research that suggests teachers 'beliefs about standardized tests are mostly negative, there are also studies that show that teachers' beliefs are both positive and negative [31], [32] found that teachers found it useful to make comparisons between students via standardized tests; however the limitations of these tests were far more than beneficial.

Teachers state that standard tests are causing stress for them and that these tests are not a valid way to measure students' learning. When the relevant literature is examined, it is seen that teachers' beliefs about standard tests are negative as well [33]. [34] state that primary and secondary school teachers believe that standardized tests are waste of time, does not comply with the goals that the curriculum and are very poor in reflecting students' knowledge and skills. According to [35] a large number of teachers believe that the standardized tests are do not point the schools in the right direction and the results of one-off tests are not an accurate indicator of student learning and development. In addition, teachers believe that standard tests have negative effects on curriculum, learning-teaching, student-teacher motivation.[36] indicate that teachers believe that their own tests provide more information than the standardized tests in terms of assessment and evaluation. According to [17] teachers express that standard tests produce "teaching of the test techniques" on teachers. Teachers also believe that using standardized testing leads to the labeling of students. Although teachers find standardized tests valid and useful in the classroom context when the focus shifts away from the classroom context and is to make decisions regarding the students' future or future school life very little teachers show the same supportive attitude towards these tests. According to [37] $95 \%$ of teachers state that standardized tests are causing more stress and they feel pressure because of increasing test practices and accountability [38] [39], [40]. In addition, the use of 
standardized tests reduces teachers' job satisfaction and simplifies teaching and learning activities. Standard tests require the teaching of the test technique, teachers' rethinking important content, and cause some content to be preferred to others [41] inform that with the use of standardized tests teachers change their teaching style and are forced to focus on a more teacher-centered teaching. Besides student interest and motivation decreases and these tests create a less inclusive classroom environment for students coming from disadvantaged groups.

For teachers, the use of standardized tests limits professionalism and the positive effect in instructional decisions. In addition, based on the result of a single exam, teachers are forced to defend their in-class actions [42]. Standardized tests used in determining teacher competencies do not provide excellence in accountability or teaching It is stated that the standard tests used in teacher selection have the potential to exclude visible minorities and alternative thinkers who have a world view that can enrich the education system [43].

When the findings are examined, significant difference is found among the beliefs of the teacher candidates regarding the standardized tests in terms of gender variable. As a result of this research, male teacher candidates' beliefs regarding the objectivity of standardized tests, beliefs about high-stakes decisions and beliefs about bonus money based on standardized tests were found to be higher than female teacher candidates. [17] indicated that male teachers believe more that the intelligence tests which are a type of standard tests give better ideas about students' intelligence compared to female teachers. [44] stated that the teacher beliefs about the effects of standard tests do not show any significant difference according to the gender variable. As being for or against standardized tests is highly influenced by the individual's epistemological beliefs, it is important to consider how differences in worldviews shape the assumptions of people about tests while discussing these tests [26].

Another finding of the study is that there is a meaningful difference between teacher candidate's beliefs in terms of branch variable. The teacher candidates who had more belief in standardized tests were those studying in mathematics-science and social sciences field. It was also determined that the teacher candidates with the lowest beliefs for standardized tests were teacher candidates who study in special skills (e.g. art, music) and primary education field. Teacher candidates in primary education field are expected to work in elementary schools and kindergarten in the future. In their professional lives, they use of process assessment tools such as developmental files much more than standardized tests as they have no testing obligations. Teacher candidates who study in areas requiring special skills are enrolling to the programs with a special aptitude test besides standardized tests. Thus the importance of these tests is secondary for them. Besides they will not be using any standardized test for their students and they have not experienced effects of these tests as teacher candidates in other fields. It is not surprising that that the beliefs of the teacher candidates in these two areas are low for the standard tests. In the field of mathematics and science, teacher candidates enroll to the programs only by achieving standardized tests and they are exposed to these tests more in their educational backgrounds. Teacher candidates studying in these areas are also experience those test much more and have awareness that they will use standard tests frequently in their professional lives. It can be argued that this case is one of the reasons for the teachers of science and mathematics and social sciences candidates to have higher beliefs in standard tests than those in other fields. According to [45] it is difficult to distinguish teachers from their past and school experiences. At this point, the teacher candidates' internal talks on teaching and the beliefs about learning and teaching should be heard first when they sign up to the education faculty. [46] indicated that teacher candidates' beliefs can change or be shaped within certain parameters. In this direction, it is possible for a teacher candidate with a student-centered teaching tendency to develop more sensitive ideologies with special support. [47] pointed out that the beliefs of unconventional and successful students following a different career are highly influenced by past experiences while the beliefs of traditional students are shaped more within past school experiences. From this point it can be said that teacher candidates' educational experiences and background are very important in terms of beliefs about the standardized tests. Thus it can be said that the teacher education programs should take more responsibility in helping teacher candidates to develop more original perspectives on the new philosophy and paradigms.

When the findings of the second question of the research are examined, it is determined that the grade variable had no significant effect on the beliefs of the teacher candidates about the standard tests. In other words, it can be said that the education process of the candidates in the education faculty has no effect on their beliefs about the standardized tests, which are mostly related to the traditional learning and teaching process. [48] informed that the individual experiences and the experiences gained during the student years are effective on the teachers' beliefs. Besides teaching-learning practices are influential in shaping students' beliefs in learning [49]. According to this, because the teacher candidates participating in the research go on their education at the same faculty, they have had similar learning experiences even though they are in different grades. Therefore, it is expected that the teacher candidates who have similar experiences are close in the context of the belief levels for the standardized tests.

According to the results of the study the following suggestions are made;

1. It is important to carry out researches that will examine teacher candidates' other educational 
beliefs together that may relate to the beliefs about standard tests.

2. Investigating the teacher candidates' beliefs about standardized test during selecting, preparation and practicing the job phases will provide a holistic understanding the nature of teacher candidates' beliefs regarding standardized tests.

3. It is recommended that methods and techniques that will ensure developing teacher candidates' beliefs about standard tests in accordance with the educational philosophy of the country should be included in teacher training programs.

\section{Appendix A}

\section{Beliefs about Standardized Tests Scale (Magee and Jones, 2012)}

1. Standardized tests are the best way to objectively measure how much a student knows.

2. Students are too different for a single standardized test to really be useful in measuring their abilities.

3. A good standardized test can provide a fair (unbiased) indication of the quality of education a student receives in school.

4. True knowledge is too complex to be measured by a standardized test.

5. It is impossible for a standardized test to really be unbiased.

6. It is a good idea for states to require all high school students to pass a standardized test or set of standardized tests in order to graduate from high school.

7. Students, in any grade above third grade, who do not pass their grade-level standardized test should have to repeat that grade level.

8. Schools whose students have the highest scores on standardized tests should receive bonus money.

9. Teachers whose students score the highest on standardized tests should receive bonus money.

\section{Turkısh Version of the Beliefs about Standardized Tests Scale Used in this Study}

(Adapted into Turkish by İlhan, Çetin and Kinay, 2015).

1. Standart testler bir öğrencinin ne kadar bildiğini objektif olarak ölçmenin en iyi yoludur.

2. Öğrenciler çok farklı özelliklere sahip olduğundan, öğrencilerin yeteneklerini ölçmede standart bir test yararlı olmaz.

3. İyi bir standart test, öğrencilerin okulda aldığı eğitimin kalitesi ile ilgili yansız bir gösterge sağlayabilir.

4. Gerçek bilgi, standart test ile ölçülemeyecek kadar karmaşıktır.
5. Standart testlerin gerçekten tarafsız (yansız) olması imkânsızdır.

6. Ülkelerin, liseden mezun olabilmeleri için tüm öğrencilerinden bir veya daha fazla standart testte başarı olmalarını istemeleri iyi bir fikirdir.

7. Üçüncü sınıfın üstündeki tüm sınıflarda, kendi sınıf düzeyindeki standart testlerde başarılı olamayan öğrenciler sınıf tekrarı yapmalıdır.

8. Standart testlerden en yüksek puanı alan öğrencilerin okulları para ödülü almalıdır.

9. Standart testlerden en yüksek puan alan öğrencilerin öğretmenleri para ödülü almalıdır.

\section{REFERENCES}

[1] Fishbein, M., \& Ajzen, I. Belief, Attitude, Intention, and Behavior: An Introduction to Theory and Research. Reading, MA: Addison-Wesley, 1975.

[2] Pajares, M. F. Teachers' beliefs and educational research: Cleaning up a messy construct. Review of educational research, 62(3), 307-332, 1992.

[3] Sang, G., Valcke, M., van Braak, J., \& Tondeur, J. Investigating teachers' educational beliefs in Chinese primary schools: socioeconomic and geographical perspectives. Asia-Pacific Journal of Teacher Education, 37(4), 363-377, 2009.

[4] Nespor, J. The role of beliefs in the practice of teaching. Journal of curriculum studies, 19(4), 317-328, 1987.

[5] İlhan, M., Cetin, B. \& Bars, M. Katılımcı Değerlendirmeye Yönelik Inanç Ölçeği'nin (KDYİÖ) Türkçe Uyarlaması: Geçerlik Ve Güvenirlik Çalıșması. Journal of Europan Education, 3(2), 17-35, 2013.

[6] Özturgut, O. Standardized Testing in the Case of China and the Lessons to Be Learned for the US. Journal of International Education Research, 7(2), 1, 2011.

[7] Kempf, A. (2016). The pedagogy of standardized testing: The radical impacts of educational standardization in the US and Canada. Springer.

[8] Dolezalek, H. (2008). Standardized testing in schools. ABDO

[9] Bhattacharyya, S., Junot, M., \& Clark, H. Can you hear us? Voices rose against standardized testing by novice teachers. Creative Education, 4(10), 633, 2013.

[10] Popham, W. J. Why standardized tests don't measure educational quality. Educational leadership, 56, 8-16, 1999.

[11] Koç, N. Standart Başarı Testlerinin Bir Eğitim Sisteminde Verilen Çeşitli Kararlardaki Yeri ve Önemi. Ankara Üniversitesi Eğitim Bilimleri Fakültesi Dergisi, 17(1). 1984.

[12] Richardson, P. K. Use of Standardized Tests in Pediatric Practice. Occupational Therapy for Children-E-Book, 216, 2013.

[13] Sefcik, D., Bice, G., \& Prerost, F. How to study for 
standardized tests. Jones \& Bartlett Publishers 2012.

[14] Dalal, J., \& Gunderman, R. B. Standardized tests: a review. Journal of the American College of Radiology, 8(4), 271-274, 2011.

[15] Holmes, S. Standardized testing and the No Child Left behind Act: A failing attempt at reform. East Carolina University Library, 2009.

[16] Kelleghan, T., Madaus, G. F., \& Airasian, P. W. The effects of standardized testing (Vol. 1). Springer Science \& Business Media, 2012.

[17] Gawthrop, J. Measuring student achievement: A study of standardized testing and its effect on student learning, 2014

[18] GL Assessment, A short guide to standardized tests. Great Britain, 2013.

[19] Yeh, S. S. Limiting the unintended consequences of high-stakes testing. Education Policy Analysis Archives/Archivos Analíticos de Políticas Educativas, 13, 2005.

[20] Steeves, K. A., Hodgson, J., \& Peterson, P. Are we measuring student success with high-stakes testing?. In The Educational Forum (Vol. 66, No. 3, pp. 228-235). Taylor \& Francis Group, 2002.

[21] Kamenetz, A. The Test: Why Our Schools are obsessed with Standardized Testing but You Don't Have to Be. Public Affairs, 2015.

[22] McNeil, L. Contradictions of school reform: Educational costs of standardized testing. Routledge, 2002.

[23] Harris, P., Smith, B. M., \& Harris, J. The myths of standardized tests: Why they don't tell you what you think they do. Rowman \& Littlefield Publishers, 2011.

[24] Kohn, A. The case against standardized testing: Raising the scores, ruining the schools. Portsmouth, NH: Heinemann, 2000 .

[25] Magee, R.G., \& Jones, B.D. An Instrument To Assess Beliefs About Standardized Testing: Measuring The Influence Of Epistemology On The Endorsement Of Standardized. Australian Journal of Educational \& Developmental Psychology, 12, 71-82, 2012.

[26] Karasar, N. Bilimsel araştırma yöntemi (19. Bask1). Ankara: Nobel Yayın Dağıtım, 2009.

[27] İlhan, M., Çetin, B. ve Kinay, İ. Standart Testlere Yönelik İnanç Ölçeği'nin (Styiö) Türkçe Uyarlaması: Geçerlik ve Güvenirlik Çalışması. Mustafa Kemal Üniversitesi Sosyal Bilimler Enstitüsü Dergisi (Mustafa Kemal University Journal of Social Sciences Institute), 12 (29), 161-189, 2015.

[28] Raines-Eudy, R. Using Structural Equation Modeling To Test for Differential Reliability and Validity: An Empirical Demonstration. Structural Equation Modeling: A Multidisciplinary Journal, 7(1): 124-141, 2000.

[29] Pallant, J. SPSS Survival Manual: A Step by Step Guide to Data Analysis Using SPSS for Windows. Australia: Australian Copyright, 2005.

[30] Akbulut. Y. Sosyal Bilimlerde SPSS Uygulamaları. İstanbul: İdeal Kültür Yayınc1lık, 2010.
[31] Cimbricz, S. State-mandated testing and teachers' beliefs and practice. Education Policy Analysis Archives, 10(2), 2002.

[32] Al-Bataineh, A., \& Gunn, J. Majedah, Abu A. Teachers' Perceptions of High-Stakes Testing. In Proceedings of International Academic Conferences. International Institute of Social and Economic Sciences, 2016.

[33] Schuette, Christine T.; Wighting, Mervyn J.; Spaulding, Lucinda S.; Ponton, Michael K.; and Betts, Anastasia L., "Factors that Influence Teachers' Views on Standardized Tests" Faculty Publications and Presentations. Paper 157. 2010. http://digitalcommons.liberty.edu/educ_fac_pubs/157

[34] Stiggins, R. J., \& Bridgeford, N. J. The ecology of classroom assessment. Journal of Educational Measurement, 22(4), 271-286, 1985.

[35] Jones, B. D., \& Egley, R. J. Voices from the frontlines: Teachers' perceptions of high-stakes testing. Education policy analysis archives, 12, 39, 2004.

[36] Leighton, J. P., Gokiert, R. J., Cor, M. K., \& Heffernan, C. Teacher beliefs about the cognitive diagnostic information of classroom versus large scale tests: Implications for assessment literacy. Assessment in Education: Principles, Policy \& Practice, 17(1), 7-21, 2010.

[37] Franklin, C. A., \& Snow-Gerono, J. L. Perceptions of teaching in an environment of standardized testing: Voices from the field. The Researcher, 21(1), 2-21, 2007.

[38] Abrams, L. M., Pedulla, J. J., \& Madaus, G. F. Views from the classroom: Teachers' opinions of statewide testing programs. Theory into practice, 42(1), 18-29, 2003.

[39] Sikka, A., Nath, J. L., \& Cohen, M. D. Practicing teachers' beliefs and uses of assessment. International Journal of Case Method Research \& Application, 3, 240-253, 2007.

[40] Klager, C. Teacher attitudes about standardized testing and test preparation: A case study (Doctoral dissertation, University of Kansas), 2013.

[41] Thompson, G., \& Harbaugh, A. G. The effects of NAPLAN: Teacher perceptions of the impact of NAPLAN on pedagogy and curriculum, 2012.

[42] Schulz, B. C., \& Schools, F. C. Teachers' perspectives of how high-stakes testing influences instructional decisions and professionalism. Reflections of the Past, Visions for the Future, 169, 2005.

[43] Portelli, J. P., Solomon, R. P., Barrett, S., \& Mujawamariya, D. Standardized teacher testing fails excellence and validity tests. Teaching Education, 16(4), 281-295, 2005.

[44] Brockmeier, L. L., Green, R. B., Pate, J. L., Tsemunhu, R., \& Bockenko, M. J. Teachers' beliefs about the effects of high stakes testing. Journal of Education and Human Development, 3(4), 91-104, 2014

[45] Wall, C. R. G. From student to teacher: changes in preservice teacher educational beliefs throughout the learning-to-teach journey. Teacher Development, 20(3), 364-379, 2016.

[46] Luft, J. A., \& Roehrig, G. H. Capturing science teachers' epistemological beliefs: The development of the teacher beliefs interview. Electronic Journal of Science Education, 11(2), 2007 
[47] Novak, D., \& Knowles, J. G. Life Histories and the Transition to Teaching as a Second Career. Paper presented at the Annual Meeting of the American Educational Research Association (San Francisco, CA, April 20-24, 1992), 1992.

i NOTE: This research is presented as oral presentation at the $26^{\text {th }}$ International Conference on Educational Sciences 20-23 April 2017 Antalya-Turkey.
[48] Yalaza Atay, D. Öğretmen Eğitiminin Değişen Yüzü. Nobel Yayın, Ankara, 2003.

[49] Deryakulu, D. Epistemolojik İnançlar, Kuzgun, Y. ve Deryakulu, D. (Ed.).Eğitimde Bireysel Farklılıklar. Ankara: Nobel Yayın Dağıtım, Ankara, ss. 261-289, 2006. 